\title{
Performance Improvement of Basketball Athletes based on Statistical Analysis
}

\author{
Lukmannul Haqim Lubay* \\ Fakultas Pendidikan Olahraga \\ Universitas Pendidikan Indonesia \\ Bandung, Indonesia \\ *lukmanlubay@upi.edu
}

\begin{abstract}
The purpose of this study was to determine how much influence the statistical-based model for U16 year athletes. Statistical model is related to: Number of throws that are not right on target and right on target (abbreviated as FG), Number point throws (PTS), Number of assists (AST), Number of balls that bounce on the board due to miss or rebound (REB) throws, number of violations or foul (F), number of balls lost or turnover (TO), and number of balls stolen from opponents or steals (S). Based on these data, the results will be given a program based on statistical results. It is hoped that this model will be able to improve the ability of the U-14 - 16 year athletes.
\end{abstract}

Keywords-game basketball; analysis of statistical data related to the game

\section{INTRODUCTION}

Basketball games are one of the most popular sports in the world, fans from all ages feel that basketball sports games are fun, competitive, educating, entertaining, and healthy so they can be played by sons and daughters, parents, adults, teens and children. Individual skills such as shooting, dribbling, and rebounding, as well as attacking or defending teamwork, are requirements to succeed in playing this sport [1-3]. Characteristics of basketball games that are so competitive require each team to try to put the ball into the opponent's basket by using their hands to score numbers and instead try to keep their own basket so that the opponent cannot score [4].

Technically, each basketball player will display all the abilities he has to bring the team to win the match. The victory of a team depends on the individual's ability to master several techniques in basketball games such as passing, shooting, dribbling, and rebounding as well as teamwork or understanding playing to win matches $[5,6]$.

\section{MAterial AND MethoD}

In this study, researchers used the single group pretest posttest experimental method in their research taken from the results of gathering information and the symptoms that existed at the time of the study, meaning that the data was taken during the game tournament after it was given a program on the team that presented the victory a little so the magnitude of the effect of the experiment can be known with certainty. Regarding
Gall's experimental method, says that, "The experimental treatment would be the introduction of the new reading program into the daily schedule of learning activities of a group of students" [7]. Whereas Fraenkel says that "experimental research is unique in two very important respects: it is the only type of research, and when properly applied, it is the best type for testing hypotheses "about cause-and-effect relationships" [8]. Based on the explanation above, the step of this research is not limited to the data collection process of data preparation only but includes the process of analysis, treatment and interpretation of the meaning of the data obtained, The TGFU learning model has an influence on the results of learning to play basketball [9]. Some taken from the population are called research samples. Regarding this, Fraenkel explains that, "their conclusions about a group of people (students, Republicans, football players, actors, and so on) experiences they have with a fairly small number, or sample, of individual members" [8]. Selection process to be part of the research the sample of this study were athletes $14-16$ years.

\section{RESUlt AND DISCUSSION}

The purpose of this study was to identify statistics related to the game, the most distinguishing between high and low ability players in several matches. Research in this match will see individually the needs that are needed so that in a match the ability of athletes will increase based on statistics. When analyzing all matches, it is possible to identify a small part of the game's performance indicator that distinguishes the winning and losing teams (assists, defensive rebounds, 2 and 3 field success points). Assist is an indicator of teamwork, and gives more opportunities to score goals and win [10]. Assist and turnover are not only related to the technical capacity of the players but also the decision and perception processes, which are related to, for example, team maturity or time, which is very important for printing baskets (reading defenses and knowing which is the better time to pass ball to teammate).

According to Ibáñez et al., defensive rebound has an indirect effect on the rhythm of the game, more rebounds will mean more opportunities to carry out attacks, which begin after a defensive rebound [11,12]. 3-point shots can make a difference in the outcome of the match. Some studies have focused on the importance of previous game performance 
indicators [13-15]. In recent years, it seems clear that longrange shots have a greater influence on game dynamics creating more space for players closer to the basket due to higher accuracy than three-point shooters. The players become specialists, focusing their appearance on long-range shots in a 3-point shot match can distinguish between winning and losing teams [16]. Even in junior groups and groups of 3-point shot women can determine or predict the victory of the team [15]. The results of the average match include PTS $(10,42 \%)$, ST $(2,92 \%), \operatorname{AST}(3,22 \%), \operatorname{REB}(7,67 \%), \operatorname{EFF}(4,38 \%)$.

\section{CONCLUSION}

The results of the match indicate that the team that wins and losses will be determined in the statistical results of each player. Overall, the game shows the importance of teamwork and individual qualities such as effective defensive rebounds, 2 or 3-point shots, assists and reduced errors both individually and in teams. As a limitation of research, it seems clear that quantitative analysis is not enough to understand what happened in a match. Qualitative complementary analysis is needed to explain why and how statistical results are applied in an exercise program.

\section{REFERENCES}

[1] L. Lamas, J. Barrera, G. Otranto, and C. Ugrinowitsch, "Invasion team sports: strategy and match modeling," International Journal of Performance Analysis in Sport, vol. 14(1), pp. 307-329, 2014.

[2] J. Sampaio, E.J. Drinkwater, and N.M. Leite, "Effects of season period, team quality, and playing time on basketball players' game-related statistics," European Journal of Sport Science, vol. 10(2), pp. 141-149, 2010.

[3] B. Bazanov, P. Võhandu, and R. Haljand, "Factors influencing the teamwork intensity in basketball," International Journal of Performance Analysis in Sport, vol. 6(2), pp. 88-96, 2006.
[4] FIBA, Rules Basketball. 2017.

[5] R. Bartlett, "Performance analysis: can bringing together biomechanics and notational analysis benefit coaches?," International Journal of Performance Analysis in Sport, vol. 1(1), pp. 122-126, 2001.

[6] G. Csataljay, P. O’Donoghue, M. Hughes, and H. Dancs, "Performance indicators that distinguish winning and losing teams in basketball,' International Journal of Performance Analysis in Sport, vol. 9(1), pp. 60 66, 2009.

[7] Gall, Educational Research. Eight Edition. Pearson Education, Inc, 2007.

[8] J.R. Fraenkel, N.E. Wallen, and H.H. Hyun, How to design and evaluate research in education. New York: McGraw-Hill Humanities/Social Sciences/Languages, 2011.

[9] Arviyani, Comparison of peer teaching learning models with inquiry learning models on learning outcomes of basketball games. Universitas Pendidikan Indonesia, 2017.

[10] R. Hoofler and J. Payne, Measuring efficiency in the national basket association. Econ lett, 1997; vol. 55(2), pp. 293-299.

[11] S.J. Ibáñez, J. Sampaio, S. Feu, A Lorenzo, M.A. Gómez, and E. Ortega "Basketball game-related statistics that discriminate between teams" season-long success," Eur J Sport Sci, vol. 8(6), pp. 1-4, 2008.

[12] I.R. Román, I.U.R. Durán, and J.S. Molinuevo, “Analysis of men's and women's basketball fast-breaks," Revista de Psicología del deporte, vol. 18(3), pp. 439-444, 2009

[13] T. Đurković, D. Gjergja, N. Marelić, L. Antekolović, and T. Rešetar, "The analysis of two groups of basketball teams based on the situational parameters of the game," In International Scientific Conference on Kinesiology, vol. 4, 2005.

[14] A. Karipidis, P. Fotinakis, K. Taxildaris, and J. Fatouros, "Factors characterizing a successful performance in basketball," Journal of human movement studies, vol. 41(5), pp. 385-397, 2001.

[15] S.J. Ibáñez, J. Sampaio, P. Sáenz-López, J. Giménez, and M.A. Janeira, "Game statistics discriminating the final outcome of junior world basketball championship matches (Portugal 1999)," Journal of Human Movement Studies, vol. 45(1), pp. 1-20, 2003

[16] S.J. Ibáñez, J. García, S. Feu, A. Lorenzo, and J. Sampaio, "Effects of consecutive basketball games on the game-related statistics that discriminate winner and losing teams," Journal of sports science \& medicine, vol. 8(3), pp. 458, 2009. 